\title{
Sexual Assault: Epidemiological Profile and Clinical Aspects at the Brazzaville University Hospital Center
}

\author{
L. M. E. Eouani 1,2, J. C. Mokoko",3, C. Itoua ${ }^{2,3}$, N. S. Sekangue Potokouen Mpia3, L. H. Iloki ${ }^{2,3}$ \\ ${ }^{1}$ Service de Gynécologie Obstétrique, Hôpital Général de Loandjili de Pointe-Noire, Pointe-Noire, Congo \\ ${ }^{2}$ UniversitéMarien NGOUABI de Brazzaville, Brazzaville, Congo \\ ${ }^{3}$ Service de Gynécologie Obstétrique, Centre Hospitalier Universitaire de Brazzaville, Brazzaville, Congo \\ Email: eouani@yahoo.fr, eouanilevymax@gmail.com
}

How to cite this paper: Eouani, L.M.E., Mokoko, J.C., Itoua, C., Mpia, N.S.S.P. and Iloki, L.H. (2020) Sexual Assault: Epidemiological Profile and Clinical Aspects at the Brazzaville University Hospital Center. Open Journal of Obstetrics and Gynecology, 10, 326-332.

https://doi.org/10.4236/ojog.2020.1020029

Received: August 16, 2019

Accepted: February 25, 2020

Published: February 28, 2020

Copyright $\odot 2020$ by author(s) and Scientific Research Publishing Inc. This work is licensed under the Creative Commons Attribution International License (CC BY 4.0).

http://creativecommons.org/licenses/by/4.0/

\begin{abstract}
Objective: to identify the socio-demographic profile of the alleged victims of sexual assault, to define the characteristics of the aggressors, to describe the types of clinical lesions, and to analyze the link between these different parameters. During the study period, 5620 clients were admitted to gynecological emergencies, including 150 for sexual assault (2.6\%). The alleged victims of aggression were 14 years old on average [range: 2 - 49 years]. Among these clients, there were 147 (98\%) women and 3 (2\%) men [sex ratio: 0.02]. They had a primary education level of $38 \%$, secondary to $42.7 \%$, and single in 87.2\% of cases. Clients came from home (69.3\%) or police station $(24.7 \%)$. The perpetrator was male, with an average age of 25.5 years [range: 16 to 35 years]. Regarding the relationship with the victim, the neighborhood accounted for $83 \%$. The perpetrator was alone in $76.7 \%$ of cases, two $(14 \%)$ or more (16.7\%), up to 18 . The aggressor's home was the place of aggression (39.3\%). The threats were made using knives (49.3\%) and firearms (8.5\%). The perpetrator used either his sex (79.9\%), his fingers $(34.2 \%)$ or an object (2.7\%). The route of entry was vaginal (94.6\%), anal (21.7\%) and oral (10\%). The abuser used the condom in $74.7 \%$ of cases. Customers had viewed within 24 hours (40.7\%). The general state and hemodynamics at admission was normal for all clients. Physical injuries were injuries (23\%) and scrapes (34.5\%). External genitalia included perineal tears (28\%), vaginal tears $(8.6 \%)$, hymenal tears $(7.3 \%)$, and old deflowering $(72.7 \%)$. The hymen was intact in $20 \%$. The bi-varied analysis found a correlation with a statistically significant difference in the age range of the alleged victims with the number of aggressors, the time of aggression, the path and type of penetration, and the weapon used for the threat.
\end{abstract}




\section{Keywords}

Sexual Assault, Firearm, Stab, Perineal Tear, Vaginal Tear, Hymenal Tear

\section{Introduction}

The care of alleged victims of sexual assault is a situation encountered in consultation in the gynaecological emergency services. According to the WHO, the annual rate of sexual assault worldwide can reach 800,000 people, and its prevalence is poorly known [1]. In the USA, its frequency varies between $15 \%$ and $25 \%$ of the female population in France, over a year 553,000 women aged 20 to 69 years report having been the victim of at least one sexual assault other than rape (touching of sex, breasts, buttocks and exhibition) and 62,000 women report being raped [2]. In Africa, the incidence of sexual violence ranges from $0.4 \%$ to $4.4 \%$ [3]. Sexual assault poses the problem of psychosocial impact and psychopathological sequelae. Despite this, it is neglected by most of the parties involved [4].

The lack of data and its growing incidence motivated this work whose general objective is to describe the epidemiological, clinical aspects of sexual violence at the University Hospital of Brazzaville, and specifically, to identify the socio-demographic profile alleged victims, define the characteristics of perpetrators, identify the types of clinical injuries, and the involvement of justice.

\section{Patients and Method}

The study was carried out in the Obstetrics Department of the University Hospital of Brazzaville from January 1, 2014 to December 31, 2016 or 24 months. It concerned all alleged victims of sexual violence admitted to the gynaecological emergency room. It was a retrospective and analytical study.

Patients who reported sexual violence, either came from themselves, or received on request from a doctor, had been included.

Patients who had not been included were consulting for trauma after consensual sex, cases of misappropriation of minors and cases of unexploitable violence.

Gynecological emergency records, as well as medical records, were used to collect the data. The variables studied were: the socio-demographic characteristics of the alleged victims of sexual assault, the characteristics of the perpetrator, the possible injuries found, and legal involvement. The data was collected using a fact sheet and recorded from CSPRO software. Data processing and statistical analysis are done using STATA and Microsoft Excel software. We used the chi-two correlation test in this work to analyze the link between two qualitative variables. We also used proportional tests to compare the proportions of the different samples. The average test was used for numerical variables by age group. 


\section{Results}

During the study period, 5620 clients were received in gynaecological emergency departments, including 150 for sexual assault or $2.6 \%$. Socio-demographic characteristics were represented by Table 1 . The average age of alleged assault victims was 14 years, with extremes ranging from 2 to 49 years. Among these clients, 147 (98\%) women and $3(2 \%)$ sex ratio of 0.02 . They had a primary education level at $38 \%$, secondary at $42.7 \%$, and single in $87.2 \%$ of cases. Clients came from home in $69.3 \%$ of cases, followed by the police station in $24.7 \%$ of cases. The perpetrator characteristics were represented by Table 2 . He was male, with an average age of 25.5 years, extremes ranging from 18 to 35 years. In terms of the relationship with the victim, the neighbourhood represented $56.1 \%$. The perpetrator was most often alone in $76.7 \%$ of cases, but there could be two

Table 1. Sociodemographic characteristics of alleged victims.

\begin{tabular}{|c|c|c|}
\hline & Squad & Percentage \\
\hline \multicolumn{3}{|l|}{ Age range } \\
\hline$<10$ & 46 & 30.7 \\
\hline $10-20$ & 73 & $48.6 n$. \\
\hline $21-25$ & 16 & 10.7 \\
\hline$\geq 36$ & 15 & 10 \\
\hline \multicolumn{3}{|l|}{ Sex } \\
\hline Feminine & 147 & 98 \\
\hline Male & 3 & 2 \\
\hline \multicolumn{3}{|l|}{ Education level } \\
\hline No level & 23 & 15.3 \\
\hline Primary & 57 & 38 \\
\hline Secondary & 64 & 42.7 \\
\hline Acedemic & 6 & 4 \\
\hline \multicolumn{3}{|l|}{ Profession } \\
\hline No profession & 20 & 14.2 \\
\hline Student/Student & 109 & 77.3 \\
\hline official & 4 & 2.8 \\
\hline Private sector & 1 & 0.7 \\
\hline Trader & 7 & 5 \\
\hline \multicolumn{3}{|l|}{ Marital status } \\
\hline single & 123 & 87.2 \\
\hline Free union & 8 & 5.7 \\
\hline Bride & 10 & 7.1 \\
\hline Total & 150 & 100 \\
\hline
\end{tabular}

Average age 14 years, extremes 2 and 49 years. 
Table 2. Profile of the aggressor.

\begin{tabular}{ccc}
\hline Characteristics & Squad & Percentage (\%) \\
\hline Age range & 21 & 14.0 \\
$\leq 17$ ans & 82 & 54.7 \\
$18-35$ ans & 8 & 5.3 \\
$\geq 36$ ans & 39 & 26.0 \\
Unspecified & & \\
Link with victim & 19 & 12.8 \\
Family member & 83 & 56.1 \\
Neighbor & 46 & 31.1 \\
No link & & \\
Number of attackers & 115 & 76.7 \\
1 aggressor & 10 & 6.6 \\
2 attackers & 25 & 16.7 \\
$>2$ attackers & 150 & 100 \\
Total & &
\end{tabular}

The average number of attackers was 2 with extremes of 1 and 18 aggressors.

$(6.6 \%)$ or more $(16.7 \%)$, up to $18 \%$. The alleged victim was returning from his home in $69.3 \%$.

The profile of the perpetrator, the home of the perpetrator was the place for the assault met at $39.3 \%$. Threats were made with a knife in $49.3 \%$, and the firearm in $8.5 \%$. The perpetrator used his sex in $79.9 \%$ of cases, his fingers in $34.2 \%$ of cases and an object in $2.7 \%$ of cases. The pathway of penetration was vaginal for in $94.6 \%$ of cases, in $21.7 \%$ of cases and oral in $10 \%$ of cases. The perpetrator had used condoms in $74.7 \%$ of cases.

The clinical aspects were represented in Table 3. Customers had consulted within 24 hours in $40.7 \%$ of cases. The general and hemodynamic condition at admission was normal for all clients. Physical injuries were injuries in $23 \%$ of cases, and scratches in $34.5 \%$ of cases. At the genital level, they involved perineal tears in $28 \%$ of cases, vaginal tears in $8.6 \%$ of cases, hymenal tears in $7.3 \%$ of cases, and old deflowering in $72.7 \%$ of cases. The hymen was intact in $20 \%$ of cases.

The bi-varied analysis had found a correlation with a statistically significant difference in the age of the alleged victims with the number of assailants, with the time of aggression, with the path and type of penetration, and with the weapon used for the threat (Table 4).

\section{Discussion}

Our frequency is close to that reported by Traoré [5] in Senegal (3.12\%), higher than faye [6] in Senegal (0.4\%) and lower than Lawlor [7] in South Africa (54\%), 
Table 3. Clinical aspects.

\begin{tabular}{ccc}
\hline Consultation Time & Squad & percentage \\
\hline Less than 24 hours & 61 & 40.7 \\
1 to 2 days & 50 & 33.3 \\
3 to 15 days & 22 & 14.7 \\
More than 15 days & 17 & 11.3 \\
Total & 150 & 100 \\
Injuries found & & \\
Ancient deflowering & 109 & 72.7 \\
Intact hymen & 30 & 20 \\
Hymenaltears & 11 & 7.3 \\
Vaginal tears & 13 & 8.6 \\
Perinal tears & 42 & 28 \\
injuries & 34 & 23 \\
Scrapes & 51 & 34.5 \\
\hline
\end{tabular}

Table 4. Bi-varied analysis.

\begin{tabular}{|c|c|c|c|c|c|}
\hline Correlation & $<10$ years & $10-18$ years & $18-25$ years & $>25$ years & $\mathrm{P}$ value \\
\hline \multicolumn{6}{|c|}{ Moments of aggression } \\
\hline Day & 84.8 & 69.9 & 43.8 & 20 & \multirow{2}{*}{$<0.05$} \\
\hline Overnight stay & 15.2 & 30.1 & 56.3 & 80 & \\
\hline \multicolumn{6}{|c|}{ Types of penetration } \\
\hline Penile & 35.6 & 94.5 & 93.8 & 93.3 & \multirow{3}{*}{$<0.05$} \\
\hline Digital & 60 & 5.5 & 6.3 & 6.7 & \\
\hline Object & 4.4 & 0 & 0 & 1.3 & \\
\hline \multicolumn{6}{|c|}{ Pathways of penetration } \\
\hline Vaginal & 93.3 & 95.9 & 100 & 86.7 & \multirow{3}{*}{$>0.05$} \\
\hline Onal & 13.3 & 18.1 & 12.5 & 78.6 & \\
\hline Oral & 6.7 & 9.7 & 18.8 & 14.3 & \\
\hline \multicolumn{6}{|c|}{ Types of threat } \\
\hline Firearm & 0 & 0 & 11.1 & 41.7 & \multirow{3}{*}{$<0.05$} \\
\hline Whipeweapon & 13.3 & 44.3 & 88.9 & 50 & \\
\hline Others & 86.7 & 45.7 & 0 & 8.3 & \\
\hline \multicolumn{6}{|c|}{ Link with the aggressor } \\
\hline Parent & 28.3 & 6.9 & 6.7 & 0 & \multirow{3}{*}{$<0.05$} \\
\hline Nearby & 54.3 & 37.5 & 6.7 & 6.7 & \\
\hline Unknown & 17.4 & 55.6 & 86.7 & 93.3 & \\
\hline \multicolumn{6}{|c|}{ Number of attackers } \\
\hline One & 95.7 & 76.7 & 68.8 & 26.7 & \multirow{2}{*}{$<0.05$} \\
\hline Two & 2.2 & 11 & 0 & 6.7 & \\
\hline More than two & 2.2 & 12.3 & 31.3 & 66.7 & \\
\hline
\end{tabular}


and Bordeaux, France, $30 \%$ of admissions to a reception centre for victims of aggression [8]. the low rates most often reported in African studies seem to do not reflect reality. The culture of family honour and own honour would prevent some women from consulting. To the extent that it is most often a family member, a close friend or the husband himself [9]. The alleged victims of violence were young, close to the perpetrator and the perpetrator's home was the most found location. This observation was also made by Leye [10] in Kolda, Senegal.

The perpetrator was young, often alone, using a knife in the majority of cases as found in most African studies [8] [9] [10] [11]. A third of our clients arrived more than 24 hours after the assault. Indeed, in our context, there is no recognized centre for the care of alleged victims of aggression as in developed countries, let alone a centre for victims of sexual assault. Those affected arrive directly from the scene of the assault to the hospital when the physical trauma is visible. But the majority come from home, because they first get in shape before going to the health centre. The sex of the perpetrator was mainly used as an object of sexual assault as found in the Amah study [12] in Togo (62.5\%) with a low condom use rate of $4.3 \%$. This has been noted in the literature reporting that the prevalence of genital contact in Sub-Saharan Africa is high, but it remains low compared to studies in developed countries [12].

We found a correlation between the progression of the presumed victim's age with the timing of the assault, the type of penetration, the type of threat, the relationship to the victim, and the number of perpetrators. According to the $\mathrm{O}$. M.S., sexual assault is a public health problem.

Our study, although hospital, noted the importance and severity of the problem. The young age of the victims, and especially child abusers are known persons, type of threat according to age, lack of condom wearing, average time is less than 24 hours, with a high rate of no prosecution

The alleged victims of this act are mainly children and adolescents.

The perpetrators are mostly people known to the victim; this explains the high rate of no legal action and therefore an out-of-court settlement. Victims' awareness of their rights and education for behavioural change may reduce this proportion of out-of-court settlement of sexual assaults.

The absence of condom use during this act puts victims at real infectious risk.

\section{Conclusion}

Sexual assaults at the Brazzaville University Hospital require multidisciplinary care involving gynaecologists, psychologists and other specialists depending on the types of injuries encountered. Strategies should be carried out to prevent events.

\section{Conflicts of Interest}

The authors declare no conflicts of interest regarding the publication of this paper. 


\section{References}

[1] Danet, S. and Olier, L. (2009) La santé des femmes en France. La Documentation Française, Paris.

[2] (2016) Ministère des familles, de l'enfance et des droits des femmes. Les viols, tentatives de viols et agressions sexuelles en France. La lettre de l'observatoire national des violences faites aux femmes, 10 .

[3] Faye Dieme, M.E., Traore, A.L., Gueye, S.M.K., Moriera, P.M., Diouf, A. and Moreau, J.-C. (2008) Profil épidémioclinique et prise en charge des victimes d'abus sexuels à la clinique gynécologique et obstétricale du CHU de Dakar. Journal de Gynécologie Obstétrique et Biologie de la Reproduction, 37, 358-364. https://doi.org/10.1016/j.jgyn.2007.11.002

[4] Monnet. R.P., SOUSSY, A., Monnet, P.B., Diamant-Berger, O. (1989) Approche psychopathologique de victimes de violences sexuelles à partir de l'expérience du service Médico-judiciaire de l'hôtel-Dieu à paris. Déviance et Société, 13, 339-351. https://doi.org/10.3406/ds.1989.1158

[5] Traoré, Y., Mounkoro, N., Teguete, I., Djiri, M.Y., Diallo, A., Bagayogo, M., Sissoko, A. and Dolo, A. (2010) Aspects Cliniques et Médico-légaux des Agressions sexuelles au CHU Gabriel Touré. Mali Medical, 25, 27-30.

[6] Mbaye, M., Gueye, M., Ndiaye-Gueye, Mame, D., Dieng, O., Niang, M.M., Diouf, A.A., Kane-Gueye, S. and Moreau, J.C. (2013) Abus sexuels dans une zone reculée du sud Sénégal: Épidémiologie et prise en charge. Tunis Medical, 91, 499-504.

[7] Lawlor, K. (2008) Child Sexual Abuse in Sub-Saharan Africa: Child Protection Implication for Development Policy Makers and Practitioners. In: Development Research Briefings, No. 3 by the Center for Development Studies at University College Dublin.

[8] Galaber, P., Benali, L. and Gromb, S. (2010) La prise en charge des victimes agression sexuelle au CAUVA: Une urgence psychologique. La revue de médecine légale, No. 1, 22-26. https://doi.org/10.1016/j.medleg.2010.02.005

[9] Nguessan, K., Bokossa, M., Boni, S., Kone, N. and Bohoussou, K. (2004) Les violences sexuelles chez la femme une réalité africaine. Médecine d Afrique Noire, 51, 306-310.

[10] Leye, M.M.M., Sck, I., Faye, A., Ndiaye, P., Camara, M.D., Diongue, M., et al. (2014) Profil épidémioloque des femmes sexuellement violentées dans la region de Kolda. Médecine d' Afrique Noire, 61, 224-228.

[11] Nguma, A. (2000) Etude multicentrique des cas de viol des personnes de sexe féminin reçues dans les hôpitaux de Kinshassa. 6eme congrès de la SAGO, Burkina Faso, 4-8 Décembre 2000, Livret des résumes. https://doi.org/10.1016/j.jgyn.2007.11.002

[12] Adama-Hondégla, A.B., Aboubakari, A.-S., Fiagnon, K., N’kamga-Tchocote, A.R., et al. (2013) Aspect épidémio-cliniques et prise en charge des agressions sexuelles chez les sujets de sexe féminin à Lomé. African Journal of Reproductive Health, 17, 67-72. 